\title{
Youth's Digital Skills and Their Vulnerability Towards Cyber Radicalism
}

\author{
Marhaeni Mega Wijayanti \\ Sociology Department Universitas \\ Airlangga \\ Surabaya, Indonesia \\ marhaeni.mega.wijayanti-2017@fisip.unair.ac.id
}

\author{
Amalia Nurul Muthmainnah \\ Digital Communication Leadership Vrije \\ Universiteit Brussel \\ Brussels, Belgium \\ amalianurulm@gmail.com
}

\begin{abstract}
The usage of the internet as a tool to spread terrorism is widely viewed as one of the most important security issues today. Through the internet, it is believed that propaganda and radicalism could easily spread, particularly to young people. This is because young people, regarded as digital native have higher proficiency in digital literacy and capability. This paper will discuss the counterterrorism strategy to prevent young people from embracing terrorism. Then, it will examine the correlation between digital skills and the vulnerability regarding radicalism that comes with the affordances of the Internet. This paper found that contrary to the popular expectations, youth have limited digital skills and have low coping capacities to combat online radicalism. Digital literacy from the older generation is crucially needed to guide them in dealing with this issue.
\end{abstract}

Keywords-youth, digital skills, digital natives, terrorism, online radicalism

\section{INTRODUCTION}

As the information and communication technology (ICTs) keep developing each day, our chances to access the Internet are also increasing. In Indonesia, the number of internet users has increased by 51\% from 2016 to 2017[1]. A survey by Asosiasi Jasa Pengguna Internet Indonesia reveals that more than $82 \%$ young generation (from the range of age 20-29 years old) used the Internet on a daily basis in 2016 . The Internet use by younger age (10-14 years old) even reached $100 \%$, much higher than the old generation $(>30$ years old)[2]. Whereas, research has shown that, the growth of children and youth's opportunities for online access closely correlates with their exposure to risks of internet misuse [3]. This includes the risk to be brainwashed by the propaganda of terrorism and violent radicalism.

Although some scholars are still sceptical about the causal relationship between the Internet and the increasing number of radicalisms, it is undeniable that the Internet could be a powerful terrorism strategy asset. Besides the anonymity and low cost of access, this technology has transformed the propaganda dimension of terrorist groups. 'For the first time, terrorists not only say what they want but choose when and where to say it' [4]. Without the filter of conventional mass media (such as newspaper, radio, and TV), it is easier for radical groups to persuade propaganda to their audience.

Concerns for youth regarding terrorism propaganda risk are mostly on the psychological aspect. It is believed that youth are vulnerable to be radicalized because they are in the middle of a process where life-determining choices have to be made[5]. This paper will try to explore the issue from the other aspect, by focusing on how their digital skills might affect their affordances and vulnerabilities towards propaganda of terrorism or radicalism on the Internet. Youth, which commonly categorized as the "digital natives", are frequently assumed as the generation who master the technology. This might true to some extent, but this is also discouraging them from developing the higher level of digital skills. By understanding their level of digital skills, this paper will examine their coping capacities and how it makes them vulnerable towards online radicalism risks.

\section{RESEARCH METHOD}

This paper is a result of critical analysis and exploration of the existing studies and researches related to youth, digital skills, online vulnerability, and how the Internet is affecting terrorism. Thus, data collection is done through literature review.

\section{A. Youth and Their Digital "Nativity}

Born and raised in a digital environment, young people are equipped with digital capacity. For those equipped with digital capacity and literacy, Prensky (2001) call them digital natives while those who lack proficiency as digital immigrants [6]. Their high exposure to digital media leads to the assumption that youth are superusers of technology, or on other words, a tech-savvy.

As skillful users, digital natives closely correlate with digital skills. There are indeed diverse terms and definitions regarding digital skills, but one of the most imminent and most used approaches might be from Van Dijk \& Van Deursen [7]. They introduced a framework of six digital skills: (1) Operational skills; (2) Formal skills; (3) Information skills; (4) Communication skills; (5) Content skills; and (6) Strategic skills. The first two is specific to the medium, and the other four digital skills are content-related. In order to govern content-related skills, a person first needs to have sufficient medium skills.

Prensky's claims on digital skills of digital natives will only be granted as true, if the skills considered are only the medium- related skills, in which also called as button knowledge. These skills account for the technicalities of media use. For instance, sending or receiving an email (operational skills) and using hyperlinks while browsing the internet (formal skills). Problems on youth come on the higher-level skills: content-related skills. Having proficiency in information skills means a person should be able to define the information problem, choose a website or search system to seek information, define search queries, select 
information, and evaluate information sources [7]. However, research showed that young people tend to have "satisficing" (the first piece of information is good enough) and "snaffling" (click on the first link in the results list) behavior [8]. Most of them indeed not relying on Wikipedia, but it is not because they understand how to distinguish or authenticate sources on the internet. It is only because their teachers/lecturers told them not to do so.

Van Dijk \& Van Deursen's experiment in the Netherlands even reveals that older generations actually perform better in content-related and strategic skills than the younger generations. Unfortunately, older generations are impeded by their low level of medium related skills. Which means, older people might not as tech-savvy as a youth, but they do have a better understanding of critically assess information. Experience in life certainly has some advantages here [7].

\section{B. Internet Affordances: Possible Exposure to Online}

Before going any further, it is important to understand the concept of "vulnerability" and how it relates to "affordances" and "coping capacities". Even though has not yet become a developed theory or accepted methods of measurement, the concept of "vulnerability" (and its opposite "security") has been intensively discussed in the studies of human development, geography, disaster reduction, and risk communication [9]. As summarized from Pierson [10], vulnerability is the circumstances of potential risk, which leads to disempowerment where people are actually losing power and capabilities to gain control over their lives. Vulnerability results from two factors. The external factor called as "affordances," defined as a combination of perceived and actual properties of the (Internet) technology. It is the fundamental properties that determine how the technology could possibly be used.

Therefore, for the context of this paper, the way Internet content could go viral directly is the affordances that make youth as active Internet users become vulnerable towards online radicalism. The 'high and increasing levels of always-on Internet access and the production and wide dissemination - and thence easy availability - of large amounts of violent extremist content online may have violent radicalizing effects, which certainly appears to be one of the main purposes of its producers' [11].

However, determining the significant role of the Internet in terrorism and radicalism (particularly through a technological determinism perspective) is not the goal of this paper. This paper has a narrower remit: it contextualizes research in this area to date and correlates it with youth's (lack of) digital skills, which will be explained in the next section.

\section{Internet Affordances: Possible Exposure to Online}

While "affordances" is the external factor of vulnerability, "coping capacities" on the other hand is the internal one. It refers to the ways that consumers (in this case, Internet users particularly youth) are able (or not) to harness themselves against a vulnerability in their everyday social media practices [10]. Borrowing the concepts from Lanier \& Saini in Pierson [10], there are two central aspects that need to be considered in order to understand and situate a person's coping capacities: control and consumer knowledge. Control is the way a person could enable or disable who is present or who can approach him/her. In order to exercise the control, consumer knowledge refers to the degree to which consumers are literate about the issue. In this context, it is how Internet users understand the affordances of the Internet that could be used by terrorist organizations.

Thus, it correlates these two aspects with youth's digital skills; it could be said that youth has low coping capacities. Since, as mentioned earlier, they have problems regarding content-related skills. If youth is too naïve to distinguish reliable information, it will be easier for them to be brainwashed by extremist groups who provide online content that capitalizes on the paranoia and ignorance of people who visit their sites. These extremist groups usually provide "Theories" -often supported by "evidence" that includes references to a higher power- are developed to blame an identifiable group for perceived injustices and wrongs in the world' [12]. Which then encourage their sites' visitor to support them by acting or contributing resources. Another example of the naiveness of youth is the fact that they are not aware of the commercialization of many internet sites. For instance, social media like Facebook is using an algorithm to give a specific message (ads) to a specific group of people. This technique called "narrowcasting," which turns out also being employed by terrorist organizations. The report shows that 'Al- Qaeda's online magazine has included articles written specifically to appeal to women and glorify the martyrdom of other females' [12].

Seeing how terrorist groups could "manipulate" information on the Internet, it is indeed important for youth to have a certain degree of digital skills. Youth need to learn how to access information efficiently and how to assess information critically. Selwyn (2009) mentioned that '[...] rather than concentrate solely on the technical training of young people, efforts also need to be made to explore the ways in which "critical digital literacies" can be developed' [13]. But, the adherence to the idea of a tech-savvy generation of users has fostered the perception that young people already have the necessary skills to use ICTs when seeking information. As a result, teachers do not integrate the teaching of information- seeking skills into curriculum programs [8].

\section{CONCLUSION}

Internet usage has been significantly influential in the radicalism spread. This study identifies that young people often become the easiest, yet most vulnerable target towards cyber radicalization. Considering the consequence, we assume that it is urgently needed to strengthen digital literacy among them, including content creation, critical thinking, and digital awareness. High exposure of internet and constantly communicating through digital media do not automatically mean that youth are skillful users. Yet, frequent tendency to "celebrate" the abilities of young people to learn for themselves about technology leads to a lack of attention to the important role of schools and parents in the development of digital skills. Therefore, it is obligatory to teach content-related skills in order to ensure the youth's coping capacities so that they can "tackle" cyber radicalism. 


\section{REFERENCES}

[1] Pratama, Aditya Hadi, (Internet Users in Indonesia as the Largest in the World) "Perkembangan Pengguna Internet di Indonesia Tahun 2016 Terbesar di Dunia," Thecinasia (January 30, 2017). [Online]. Avalaible: https://id.techinasia.com/pertumbuhan-pengguna-internetdi-indonesia- Tahun-2016.

[2] Sugiharto, B., (Internet Usage Dominated by Youth) "Pengguna Internet di Indonesia Didominasi Anak Muda," CNN Indonesia (October 24, 2016) [Online]. Avalaible: https://www.cnnindonesia.com/teknologi/20161024161722-185167570/pengguna-internet-di-indonesia-didominasi-anak-muda/

[3] Livingstone, S., Kirwil, L., Ponte, C., \& Staksrud, E., "In their own words: What Bothers Children Online?" European Journal of Communication, 29(3), 2014, pp. 271-288.

[4] Soriano, M., "The Vulnerabilities of Online Terrorism. Studies in Conflict \& Terrorism," 35(4), 2012, pp. 263-277.

[5] Apart, Thomas More, "Strengthening Resilience Against Violence Radicalization (STRESAVIORA)," [Online]. Avalaible: https://www.bounce-resilience-

tools.eu/sites/default/files/content/download/files/stresaviora_research r eport_summary_0.pdf

[6] Prensky, M., "Digital Natives, Digital Immigrants. On the Horizon," Marcprensky 2001 9(5), [Online]. Avalaible: http://www.marcprensky.com/writing/Prensky\%20\%20Digital $\% 20 \mathrm{Na}$ tives, $\% 20$ Digital\%20Immigrants\%20-\%20Part1.pdf.
[7] Dijk, J. V., \& Deursen, A. V., "Digital Skills: Unlocking the Information Society,” New York: Palgrave Macmillan, 2014.

[8] Combes, B., "Digital Natives or Digital Refugees? Why We Have Failed Gen Y?" Australia: Edith Cowan University Research Online, 2009.

[9] Villagran, J. C., "Vulnerability: a Conceptual and Methodological Review," Bonn: United Nations University - Institute for Environment and Human Security, 2006.

[10] Pierson, J., "Online Privacy in Social Media: A Conceptual Exploration of Empowerment and Vulnerability," iMinds SMIT Vrije Universiteit Brussel, 2012.

[11] Conway, M., "Determining the Role of the Internet in Violent Extremism and Terrorism: Six Suggestions for Progressing Research. Studies in Conflict \& Terrorism," 40(1), 2017, pp. 77-98.

[12] Royal Canadian Mounted Police. (n.d.)., "Youth Online and at Risk: Radicalization Facilitated by the Internet," Canada: Royal Canadian Mounted Police, 2011.

[13] Selwyn, N., "The Digital Native - Myth and Reality," Aslib Proceeding Vol. 61 Issue: 4 (2009), pp.364-379 [Online]. Avalaible: https://doi.org/10.1108/00012530910973776. 